\title{
HUBUNGAN USIA, JENIS KELAMIN, DAN KADAR TRIGLISERIDA SERUM DENGAN KEJADIAN KARSINOMA KOLOREKTAL DI RSUD Dr. H. ABDUL MOELOEK TAHUN 2016-2018
}

\author{
Indra kumala1, Eko Purnanto ${ }^{2}$, Festy Ladyani Mustopa ${ }^{3}$, Alex Leo Saputra ${ }^{4}$ \\ ${ }^{1}$ Departemen Bedah, RS Kota, RSUD Dr. A. Dadi Tjokrodipo \\ ${ }^{2}$ Departemen Bedah, RSPA, RSUD Pringsewu \\ ${ }^{3}$ Departemen Gizi Medik, Program Studi Kedokteran Universitas Malahayati \\ ${ }^{4}$ Program Studi Kedokteran Umum, Fakultas Kedokteran Universitas Malahayati
}

[Stella.stelli88@gmail.com]

\begin{abstract}
The Correlation Between Age, Sex, and Trigiseride Serum With Carcinoma Collorectal in Abdul Moeloek Hospital 2016-2018. Health problems of community have shifted from infectious to degenerative and malignancy. Incidence of colorectal carcinoma, tends to increase. Exact cause of colorectal carcinoma is not known, but there several risk factors that can increase occurrence this disease, including age, gender, and triglyceride levels. Purpose of this research to known cause of sex, age, and serum triglyceride levels to incidence colorectal carcinoma in Abdul Moeloek Hospital period 2016-2018. This research using cross sectional approach. Samples in were all colorectal carcinoma patients at Abdul Moeloek Hospital 2016-2018. Sampling techniques is total sampling of 65 respondents. Data analized using chi-square. Result of this research is known frequency distribution of carcinoma events more incidence of positive carcinoma (70.8\%). Age of colorectal carcinoma is most age of $\geq 50$ years (52.3\%). Sex of colorectal carcinoma patients by most males (53.8\%). Level of serum triglycerides of colorectal carcinoma patients with a high rate (55.4\%). There is no significant relationship between age and incidence of colorectal carcinoma ( $P$-value: 0.060$)$. There is a significant relationship between sex and incidence of colorectal carcinoma ( $P$-value: 0.000) and there is a significant link between serum triglyceride levels and colorectal carcinoma (P-value: 0.027). Conclusion there is meaningful relationship between gender and serum triglyceride levels with colorectal carcinoma but there is no relationship between age and incidence of colorectal carcinoma.
\end{abstract}

Keywords : Age, Sex, Triglyceride levels, Colorectal Carcinoma

\begin{abstract}
Abstrak : Hubungan Usia Jenis Kelamin Dan Kadar Trigliserida Serum Dengan Kejadian Karsinoma Kolorektal Di Rumah Sakit Umum Daerah Abdul Moeloek Tahun 2016-2018. Masalah kesehatan masyarakat telah bergeser dari penyakit infeksi ke penyakit degeneratif dan keganasan. Insiden keganasan, khususnya karsinoma kolorektal cenderung meningkat. Penyebab pasti karsinoma kolorektal belum diketahui, namun ada faktor risiko yang dapat meningkatkan terjadinya penyakit ini, diantaranya usia, jenis kelamin, dan kadar trigliserida. Tujuan dari penelitian ini mengetahui hubungan usia, jenis kelamin, dan trigliserida serum dengan karsinoma kolorektal di RSUD Abdul Moeloek 2016-2018. Penelitian ini menggunakan pendekatan cross sectional dengan sampel seluruh pasien karsinoma kolorektal di RSUD Abdul Moeloek 2016-2018. Teknik pengambilan sampel menggunakan total sampling yang berjumlah 65 responden. Analisis data menggunakan uji chi-square. Hasil dari penelitian distribusi frekuensi kejadian karsinoma lebih banyak kejadian karsinoma positif (70,8\%). Usia pasien karsinoma kolorektal paling banyak usia $\geq 50$ tahun $(52,3 \%)$. Jenis kelamin pasien karsinoma kolorektal paling banyak laki-laki $(53,8 \%)$. Kadar trigliserida serum pasien karsinoma kolorektal paling banyak dengan kadar 55,4\%. Hasil dari penelitian ini tidak terdapat hubungan yang signifikan antara usia dengan kejadian karsinoma kolorektal ( $p$-value $=0,060)$, terdapat hubungan yang signifikan antara
\end{abstract}


jenis kelamin dengan kejadian karsinoma kolorektal $(p$-value $=0,000)$, dan terdapat hubungan yang signifikan antara kadar trigliserida serum dengan kejadian karsinoma kolorektal $(p$-value $=0,027)$. Kesimpulan dari penelitian ini terdapat hubungan bermakna antara jenis kelamin dan kadar trigliserida serum dengan kejadian karsinoma kolorektal namun tidak terdapat hubungan antara usia dengan kejadian karsinoma kolorektal.

Kata Kunci : Usia, Kelamin, Trigliserida, Karsinoma Kolorektal

\section{PENDAHULUAN}

Perubahan pola hidup masyarakat menyebabkan pola penyakit pun mengalami perubahan. Masalah kesehatan utama masyarakat telah bergeser dari penyakit infeksi ke penyakit degeneratif dan keganasan. Insiden penyakit keganasan, khususnya penyakit karsinoma kolorektal cenderung meningkat setiap tahunnya. Karsinoma kolorektal adalah keganasan yang berasal dari jaringan usus besar, terdiri dari kolon (bagian terpanjang dari usus besar) dan rektum (bagian terakhir dari usus besar sebelum anus (Sudoyo, 2016).

Karsinoma Kolorektal menempati urutan ketiga setelah kanker paru dan kanker prostat pada laki-laki dan kanker payudara pada perempuan, sebagai penyebab kematian akibat kanker di Amerika Serikat. Menurut American Cancer Society, kanker kolorektal (KKR) adalah kanker ketiga terbanyak dan merupakan kanker penyebab kematian kedua terbanyak pada pria dan wanita di Amerika Serikat. Telah diprediksi bahwa pada tahun 2014 ada 96.830 kasus baru kanker kolon dan 40.000 kasus baru kanker rectum (Kemenkes, 2018).

Insiden karsinoma kolorektal mengalami peningkatan di Indonesia. Berdasarkan data pusat Patologi Anatomi dilaporkan bahwa karsinoma kolorektal termasuk dalam 10 karsinoma terbanyak di Indonesia. Dari data Globocan 2012, insiden kanker kolorektal di Indonesia adalah 12,8 per 100.000 penduduk usia dewasa, dengan mortalitas 9,5\% dari seluruh kasus kanker. Di Indonesia, kanker kolorektal sekarang menempati urutan nomor 3 (WHO, 2014). Kenaikan tajam yang diakibatkan oleh perubahan pada diet orang Indonesia, baik sebagai konsekuensi peningkatan kemakmuran serta pergeseran ke arah cara makan orang barat (westernisasi) yang lebih tinggi lemak serta rendah serat (Kemenkes, 2018)

Meskipun

perkembangan pengobatan adjuvant akhir-akhir ini berkembang secara cepat dan sangat maju, akan tetapi hanya sedikit saja meningkatkan harapan hidup pasien Kanker Kolorektal bila sudah ditemukan dalam stadium lanjut. Insiden Karsinoma Kolorektal mulai meningkat secara bermakna setelah usia 40 tahun. Insiden yang muncul sebelum usia 40 tahun biasanya terjadi bersamaan dengan faktor risiko lain, terutama faktor familial. Faktor familial akan meningkatkan risiko seseorang untuk menderita karsinoma kolorektal 3 kali lebih besar dari pada orang normal. Insiden karsinoma kolorektal pria dan wanita hampir sama, dengan rasio 1:1 (Komite Penanggulangan Kanker Nasional, 2018).

Penyebab pasti dari karsinoma kolorektal belum diketahui, namun ada beberapa faktor risiko yang dapat meningkatkan terjadinya penyakit ini, antara lain; faktor lingkungan, faktor genetik, riwayat karsinoma dalam keluarga dan kondisi medis lain seperti kolitis ulseratif (radang kolon) dan penyakit Crohn's. Risiko penyakit cenderung lebih sedikit pada wanita dibandingkan pada pria Kadar lipid darah sebagai bagian dari sindrom metabolic diperkirakan berhubungan dengan risiko kejadian karsinoma (Beberapa penelitian menyatakan bahwa kejadian karsinoma kolorektal berhubungan dengan keadaan hipertrigliseridemia (Kuipers E.J, 2016). Namun ada penelitian lain yang menyebutkan bahwa tidak ada hubungan antara kadar trigliserida serum (TGS) dengan kejadian 
karsinoma kolorektal (Jacobs T.E dkk, 2012).

\section{METODE PENELITIAN}

Jenis penelitian ini adalah penelitian penelitian analitik korelatif retrosfektif dengan menggunakan dengan pendekatan cross sectional yang bertujuan untuk mengetahui Apakah terdapat hubungan antara usia, jenis kelamin dan kadar trigliserida serum dengan kejadian karsinoma kolorektal. Penelitian ini dilaksanakan di RSUD Dr. H. Abdul Moeloek Bandar Lampung. Populasi pada penelitian ini adalah seluruh pasien Karsinoma kolorektal di RSUD Dr. H. Abdul Moeloek Periode 1 Januari 2016-31 Desember 2018 yang berjumlah 65 responden.
Pengambilan dalam penelitian ini menggunakan teknik total sampling. Pengumpulan data variabel dependen (kanker kolorektal) dan variabel independen (usia dan jenis kelamin, serta kadar trigliserida serum) dengan data sekunder dari rekam medik pasien.

Analisis bivariat dilakukan dengan menggunakan pearson test untuk mengetahui hubungan variabel independent dengan dependen.

\section{HASIL}

Berdasarkan data sekunder, diperoleh data penelitian sebagai berikut:

\section{Tabel 1. Distribusi Frekuensi Kejadian karsinoma Kolorektal}

\begin{tabular}{ccc}
\hline Kejadian Karsinoma Kolorektal & Frekuensi (n) & Persentase (\%) \\
\hline Negatif & 19 & $29.2 \%$ \\
Positif & 46 & $70,8 \%$ \\
\hline Jumlah & $\mathbf{6 5}$ & $\mathbf{1 0 0} \%$ \\
\hline
\end{tabular}

Berdasarkan tabel 1 di atas, diperoleh distribusi frekuensi kejadian karsinoma kolorektal dari 65 responden diperoleh kejadian karsinoma negatif terdapat 19 pasien $(29,2 \%)$ dan kejadian karsinoma positif terdapat 46 pasien $(70,8 \%)$.

Tabel 2. Distribusi Frekuensi Usia Pasien Karsinoma Kolorektal

\begin{tabular}{ccc}
\hline Usia & Frekuensi (n) & Persentase (\%) \\
\hline$<50$ tahun & 31 & $47.7 \%$ \\
$\geq 50$ tahun & 34 & $52.3 \%$ \\
\hline Jumlah & $\mathbf{6 5}$ & $\mathbf{1 0 0} \%$ \\
\hline
\end{tabular}

Berdasarkan tabel 2 di atas, diperoleh distribusi frekuensi usia dari 65 responden, diperoleh distribusi frekuensi usia dari 65 responden, pada usia $<50$ tahun terdapat 31 pasien $(47,7 \%)$ dan pada usia $\geq 50$ tahun terdapat 34 pasien $(52,3 \%)$.

Tabel 3. Distribusi Frekuensi Jenis Kelamin

\begin{tabular}{ccc}
\hline Jenis Kelamin & Frekuensi (n) & Persentase (\%) \\
\hline Perempuan & 30 & $46,2 \%$ \\
Laki-Laki & 35 & $53,6 \%$ \\
\hline Jumlah & $\mathbf{6 5}$ & $\mathbf{1 0 0} \%$
\end{tabular}

Berdasarkan table 3 di atas, diperoleh distribusi frekuensi jenis kelamin dari 65 responden, diketahui responden dengan jenis kelamin perempuan terdapat 30 pasien $(46,2 \%)$ 
dan laki-laki terdapat 35 pasien $(53,6 \%)$.

Berdasarkan table 4 di bawah, diperoleh distribusi frekuensi kadar trigliserida serum dari 65 responden, diketahui responden dengan kadar trigliserida normal terdapat 29 pasien $(44,6 \%)$ dan kadar trigliserida serum tinggi terdapat 36 pasien $(55,4 \%)$.

\section{Tabel 4. Distribusi Frekuensi Kadar Trigliserida Serum}

\begin{tabular}{ccc}
\hline Kadar Trigliserida Serum & Frekuensi (n) & Persentase (\%) \\
\hline Normal $(<150 \mathrm{mg} / \mathrm{dL})$ & 29 & $44.6 \%$ \\
Tinggi $(\geq 150 \mathrm{mg} / \mathrm{dL})$ & 36 & $55.4 \%$ \\
\hline Jumlah & $\mathbf{6 5}$ & $\mathbf{1 0 0} \%$ \\
\hline
\end{tabular}

Berdasarkan tabel 5 di bawah, hasil uji statistik dengan chi-square diperoleh nilai $p$-value : 0,060 ( $a>0,05)$ maka dapat diambil kesimpulan tidak terdapat perbedaan porposi kejadian karsinoma kolorektal positif antara responden usia $\geq 50$ tahun dengan responden usia $<50$ tahun. Ha ditolak artinya tidak ada hubungan yang signifikan antara usia dengan kejadian kanker kolorektal.

\section{Tabel 5. Analisis Distribusi Responden Menurut Usia Dengan Kejadian Karsinoma Kolorektal}

\begin{tabular}{|c|c|c|c|c|c|c|c|}
\hline \multirow{3}{*}{ Usia } & \multicolumn{4}{|c|}{$\begin{array}{c}\text { Kejadian Karsinoma } \\
\text { Kolorektal }\end{array}$} & \multirow{2}{*}{\multicolumn{2}{|c|}{ Total }} & \multirow[t]{3}{*}{$\begin{array}{c}p- \\
\text { value }\end{array}$} \\
\hline & \multicolumn{2}{|c|}{ Negatif } & \multicolumn{2}{|c|}{ Positif } & & & \\
\hline & $\mathbf{N}$ & $\%$ & $\mathbf{N}$ & $\%$ & $\mathbf{N}$ & $\%$ & \\
\hline $\begin{array}{l}<50 \text { tahun } \\
\geq 50 \text { tahun }\end{array}$ & $\begin{array}{c}13 \\
6\end{array}$ & $\begin{array}{l}41,9 \% \\
17,6 \%\end{array}$ & $\begin{array}{l}18 \\
28\end{array}$ & $\begin{array}{l}58,1 \% \\
82,4 \%\end{array}$ & $\begin{array}{l}31 \\
34\end{array}$ & $\begin{array}{l}100 \% \\
100 \%\end{array}$ & 0,060 \\
\hline
\end{tabular}

Tabel 6. Analisis Distribusi Responden Menurut Jenis Kelamin Dengan Kejadian Karsinoma Kolorektal

\begin{tabular}{|c|c|c|c|c|c|c|c|}
\hline \multirow{3}{*}{$\begin{array}{c}\text { Jenis } \\
\text { Kelamin }\end{array}$} & \multicolumn{4}{|c|}{$\begin{array}{c}\text { Kejadian Karsinoma } \\
\text { Kolorektal }\end{array}$} & \multicolumn{2}{|c|}{ Total } & \multirow[t]{3}{*}{ p-value } \\
\hline & \multicolumn{2}{|c|}{ Negatif } & \multicolumn{2}{|c|}{ Positif } & & & \\
\hline & $\mathbf{N}$ & $\%$ & $\mathbf{N}$ & $\%$ & $\mathbf{N}$ & $\%$ & \\
\hline Perem & 16 & $53,3 \%$ & 14 & $46,7 \%$ & 30 & $100 \%$ & 0,000 \\
\hline Laki-laki & 3 & $8,6 \%$ & 32 & $91,4 \%$ & 35 & $100 \%$ & \\
\hline
\end{tabular}

Tabel 6 di atas menunjukan hasil analisis hubungan antara jenis kelamin dengan kejadian karsinoma kolorektal diperoleh bahwa ada sebanyak 32 $(91,4 \%)$ responden berjenis kelamin laki-laki yang mengalami kejadian karsinoma kolorektal positif sedangkan diantara responden yang berjenis kelamin perempuan sebanyak 14 $(46,7 \%)$ responden dengan kejadian karsinoma kolorektal positif.
Hasil uji statistik dengan chisquare diperoleh nilai p-value : 0,000 $(a<0,05)$ maka dapat diambil kesimpulan ada perbedaan proporsi kejadian karsinoma kolorektal positif antara responden jenis kelamin laki-laki dengan responden jenis kelamin perempuan. HO ditolak artinya ada hubungan yang signifikan antara jenis kelamin dengan kejadian karsinoma kolorektal. 
Tabel 7. Analisis Kadar Trigliserida Serum Dengan Kejadian Karsinoma Kolorektal

\begin{tabular}{|c|c|c|c|c|c|c|c|}
\hline \multirow{3}{*}{$\begin{array}{c}\text { Kadar } \\
\text { Trigliserida } \\
\text { Serum }\end{array}$} & \multicolumn{4}{|c|}{$\begin{array}{c}\text { Kejadian Karsinoma } \\
\text { Kolorektal }\end{array}$} & \multicolumn{2}{|c|}{ Total } & \multirow[t]{3}{*}{ p-value } \\
\hline & \multicolumn{2}{|c|}{ Negatif } & \multicolumn{2}{|c|}{ Positif } & & & \\
\hline & $\mathbf{N}$ & $\%$ & $\mathbf{N}$ & $\%$ & $\mathbf{N}$ & $\%$ & \\
\hline $\begin{array}{l}\text { Normal }(< \\
150 \mathrm{mg} / \mathrm{dL})\end{array}$ & 13 & $44,8 \%$ & 16 & $55,2 \%$ & 29 & $100 \%$ & \\
\hline $\begin{array}{c}\text { Tinggi } \\
(\geq 150 \mathrm{mg} / \mathrm{dL})\end{array}$ & 6 & $16,7 \%$ & 30 & $83,3 \%$ & 36 & $100 \%$ & $0,0<1$ \\
\hline
\end{tabular}

Berdasarkan hasil analisis hubungan antara kadar trigliserida serum dengan kejadian karsinoma kolorektal (tabel 7) diperoleh bahwa ada sebanyak $30(83,3 \%)$ responden yang kadar trigliserida serum tinggi yang kejadian karsinoma kolorektal positif sedangkan diantara responden yang kadar trigliseridaserum normal sebanyak $16(55,2 \%)$ responden yang kejadian karsinoma kolorektal positif.

\section{PEMBAHASAN}

Hasil penelitian ini sejalan dengan penelitian Lubis M.Y dkk (2015) terhadap 246 subjek didapatkan bahwa tidak terdapat perbedaan antara usia dengan kejadian kanker kolorektal diketahui nilai p-value 0,071. Rentang usia 30-60 tahun memiliki distribusi yang besar untuk kejadian kanker kolorektal di negara Mesir dengan ratarata usia 50 tahun dan di negara Amerika 10 pasien yang terdinosa kanker kolorektal yaitu rentan usia 20 49 tahun. Belum diketahui secara jelas apa yang mempengaruhi hal ini, diduga, faktor keturunan, pola diet yang tidak sehat seperti tingginya asupan lemak dan rendahnya asupan serat, gaya hidup kebarat-baratan atau paparan lingkungan yang intens akan meningkatkan kerentanan terjadinya kanker kolorektal pada usia muda (Lubis dkk, 2015).

Namun, menurut penelitian berbeda dari American Cancer Society pada tahun 2018, menyebutkan bahwa ada dua golongan besar faktor risiko terjadinya kanker kolorektal, yaitu faktor yang dapat dimodifikasi dan
Hasil uji statistik dengan chisquare diperoleh nilai $\mathrm{p}$-value : 0,027 $(a<0,05)$ maka dapat diambil kesimpulan ada perbedaan proporsi kejadian karsinoma kolorektal positif antara responden yang Kadar Trigliserida Serum Tinggi dengan responden yang Kadar Trigliserida Serum Normal. HO ditolak artinya ada hubungan yang signifikan antara Kadar Trigliserida Serum dengan kejadian karsinoma kolorektal.

faktor yang tidak dapat dimodifikasi. Faktor yang tidak dapat dimodifikasi meliputi salah satunya adalah usia, angka insidensi kanker kolorektal lebih tinggi pada usia 50 tahun ke atas dibandingkan dengan usia 20-49 tahun. Semakin bertambahnya usia maka terdapat penurunan fungsi sel dan jaringan dalam mempertahankan struktur dan memperbaiki diri sehingga terjadi penumpukan kerusakan sel. Maka dari itu secara bertahap imun tubuh manusia akan menurun, menyebabkan banyaknya terjadi distorsi metabolik sehingga muncul penyakit degeneratif dan age-related disease seperti kanker kolorektal (American Cancer Society, 2018).

Penelitian berbeda dengan penelitian Rahdi D.R dkk, 2015 terhadap 39 responden menunjukkan bahwa terdapat hubungan yang signifikan antara usia dengan kejadian kanker kolorektal dimana kelompok usia terbanyak yang mengalami kanker kolorektal di RSUD Ulin Banjarmasin adalah usia produktif (15-64 tahun) sebesar $79,49 \%$ atau 31 pasien dan kelompok usia non 
produktif (>65 tahun) sebesar $17,95 \%$ serta paling sedikit pada usia muda (< 15 tahun) sebesar 2,56\%. Pada penelitiannya menjelaskan bahwa kemungkinan diagnosis kanker kolorektal meningkat progresif setelah usia 40 tahun dan meningkat tajam setelah usia 50 tahun. Namun, dewasa ini kejadian kanker kolorektal pada usia muda tampaknya mulai mengalami peningkatan pada beberapa individu, hal ini disebabkan karena pola hidup dan faktor keturunan (Rahdi dkk, 2015).

Hasil penelitianpun berbeda dengan penelitian Kuipers E.J dkk (2016) pada penelitiannya di Australia dan Newzeland menyatakan bahwa usia merupakan faktor risiko tertingi terhadap kejadian kanker kolorektal pada penelitiannya dijelaskan bahwa terdapat hubungan yang signifikan antara usia lanjut dengan kejadian kanker kolorektal pada penelitian ini juga menunjukkan bahwa dominan responden yang terdiagnosa kanker kolorektal adalah usia 50-70 tahun (Kuipers dkk, 2016). Oleh karena itu berdasarkan, teori, penelitian terdahulu serta hasil penelitian, peneliti berpendapat supaya penelitian selanjutnya meneliti mengenai hubungan riwayat keluarga, jenis diet dengan kejadian kanker kolorektal.Selain usia, jenis kelamin juga merupakan salah satu faktor risiko meningkatnya kejadian karsinoma kolorektal, jenis kelamin laki-laki dilaporkan merupakan faktor risiko tertinggi dalam peningkatan karsinoma kolorektal, hal ini disebabkan karena adanya efek protektif hormonal pada wanita yang menurunkan risiko untuk terjadinya karsinoma kolorektal pada wanita. Dengan adanya efek protektif hormon endogen wanita inilah yang menyebabkan prognosis karsinoma kolorektal pada wanita lebih baik dibandingkan pada laki-laki.

Penelitian sejalan dengan penelitian Lin H.J dkk (2010), menyatakan bahwa kejadian karsinoma kolorektal dipengaruhi oleh jenis kelamin dimana jenis kelamin laki-laki
$60 \%$ meningkatkan kejadian kanker kolorektal (Lin H.J dkk, 2010). Penelitian lain sejalan dengan penelitian Rahdi D.R dkk (2015) yang menyatakan bahwa selain usia, jenis kelamin memiliki perbedaan yang signifikan dengan kejadian karsinoma kolorektal dimana hasil penelitian menunjukkan bahwa responden dengan diagnosis karsinoma kolorektal didominasi oleh laki-laki yaitu sebanyak 22 orang $(56.41 \%)$ dan wanita sebanyak 17 orang (43.59\%) (Rahdi dkk, 2015).

Patomekanisme perbedaan jenis kelamin mempengaruhi terjadinya karsinoma kolorektal antara lain karena perbedaan kadar hormon antara lakilaki dan perempuan. Reseptor hormon estrogen ER $\beta$ merupakan faktor protektif terhadap KKR. Percobaan pada mencit memperlihatkan ER $\beta$ menambah proliferasi dan mengurangi diferensiasi dan apoptosis sel mukosa kolon. Estrogen juga mencegah KKR dengan mengatur mengurangi inflamasi dengan cara meng-inhibisi faktor inflamasi IL-6, yakni pada IBD yang merupakan salah satu faktor risiko KKR. Ada yang menyebutkan bahwa hormon pregesteron juga berpotensi mengurangi risiko KKR pada wanita Karena aktivitasnya dalam membantu menyintesis endogen hormon seks. Kekurangan hormon androgen pada wanita juga disebut meningkatkan risiko karsinoma kolorektal (Lin H.J dkk, 2010).

Namun hasil berbeda dengan penelitian Lubis M.Y dkk (2015) Pada 246 subjek, didapatkan bahwa tidak terdapat perbedaan antara jenis kelamin dengan kejadian karsinoma kolorektal dengan p-value 1,00 dimana dominan pada penelitian ini pasien yang terdiagnosis karsinoma kolorektal berjenis kelamin perempuan sebesar $51,6 \%$ (Lubis dkk, 2015). Trigliserida Serum yang merupakan salah satu bagian dari sindrom metabolik atau Sindroma Resistensi Insulin (SRI). Menurut American Heart Association and the National Heart, Lung, and Blood Institute, 
Sindromametabolik terdiri dari obesitas dan resistensi insulin (Kumar, dkk., 2016).

Mekanisme biologi yang diduga menjadikan TGS menjadi faktor risiko dari KKR dibagi menjadi 2, yaitu: Pertama, lemak meningkatkan pertumbuhan dan jumlah kuman anaerobik pada kolon (clostridium dan bakteriodes) yang bekerja pada lemak dan cairan empedu sehingga meningkatkan kadar asam lemak (yang sebagian besar berupa trigliserida) dan cairan empedu sekunder pada kolon. Diketahui bahwa asam lemak maupun asam empedu memulai aktivitas replikasi dan secara periodik dan simultan berperan sebagai promotor bahan lain yang potesial karsinogenik (Raluca, dkk., 2012).

$$
\text { Patogenesis Kedua adalah }
$$

diperkirakan bahwa TGS yang merupakan salah satu bagian dari sindrom metabolik atau Sindroma Resistensi Insulin (SRI). Selanjutnya kondisi hiperinsulinemi (insulin adalah hormon pertumbuhan) mempengaruhi pertumbuhan epitel sel neoplastik dan memiliki aksi mitogenik in vitro di penelitian eksperimental, baik secara langsung atau tidak langsung melalui IGF-1 (Abdullah, dkk., 2012)

Penelitian berbeda dengan Ulmer di Austria yang menyebutkan bahwa tidak ada hubungan antara kadar trigliserida serum dengan karsinoma kolorektal $(p=0,547$ untuk karsinoma kolon, dan $p=0,184$ untuk karsinoma rekti) (Tabuchi, dkk., 2012).

\section{Kesimpulan}

Hasil penelitian dari 65 responden dapat diambil kesimpulan :

1. Diketahui distribusi frekuensi kejadian karsinoma lebih banyak kejadian karsinoma positif sebanyak $70,8 \%$.

2. Diketahui distribusi frekuensi usia pasien karsinoma kolorektal paling banyak usia $\geq 50$ tahun sebanyak $52,3 \%$

3. Diketahui distribusi frekuensi jenis kelamin pasien karsinoma kolorektal paling banyak laki-laki sebanyak $53,8 \%$
4. Diketahui distribusi frekuensi kadar trigliserida serum pasien karsinoma kolorektal paling banyak dengan kadar trigliserida serum tinggi sebanyak $55,4 \%$

5. Tidak terdapat hubungan yang signifikan antara usia dengan kejadian karsinoma kolorektal ( $p$ value : 0,060)

6. Terdapat hubungan yang signifikan antara jenis kelamin dengan kejadian karsinoma kolorektal ( $p$ value : 0,000 )

7. Terdapat hubungan yang signifikan antara kadar trigliserida serum dengan kejadian karsinoma kolorektal ( $p$-value : 0,027)

\section{Saran}

Perlu diadakan lagi penelitian lebih lanjut dengan pengelompokkan usia dan kadar trigliserida yang lebih signifikan. Selin itu, perlu penelitian lebih lanjut mengenai variabel-variabel lain seperti hubungan jenis diet, faktor keturunan serta pola hidup dengan kejadian kanker kolorektal

\section{Daftar Pustaka}

Abdullah.M, Sudoyo A.W, Utomo, A.R, Fauzi A dkk, . 2012 . Molecular Profile of Colorectal Cancer in Indonesia: Is there another pathway?. RIGLD, Vol 5:71-2.

American Cancer Society. 2018. American Cancer Society Recommendations for Colorectal Cancer Early Detection. Available from:

https://www.cancer.org/cancer/c olon-rectal-cancer/detection-

diagnosis recommendations.html

Jacobs T.E, Elaine L, David SA, dkk. 2012. Sex, and Colorectal Adenoma: Results of a Pooled Analysis. The American Journal of Clinical Nutrition 83(2): 343-49. Available from: https://pdfs.semanticscholar.org/ a20d/feb3fe8f6e0c0c5edadb17b1 1d6157a70e7c.pdf

Kemenkes RI. 2018. Pedoman Nasional Pelayanan Tata Laksana Kanker 
Kolorektal. Jakarta Kementrian Kesehatan Republik Indonesia.

Komite Penanggulangan Kanker Nasional. 2018. Harapan Terpadu Kanker Kolorektal. YKI Pusat. Edisi 2

Kuipers, E.J, William M. G, David L dkk. 2016. Cancer colorectal. Journal Medical HHS Public Access 10(65) : 1-49. Available from: https://www.ncbi.nlm.nih.gov/pm c/articles/PMC4874655/pdf/nihms 769726.pdf

Kumar V, Cotran RS, Robbins SL. 2016. Buku Ajar Patologi. Edisi 7, Jakarta: EGC

Lin H.J, Edward G. 2010. Sex Hormones and Colorectal Cancer: What Have We Learned So Far. JNCL 102(23): 1-2.

Lubis. M.Y, Murdani. A, Irsan dkk. 2015. Probabilitas Temuan Kanker Kolorektal Pada Pasien Simtomatik Berdasarkan Unsur-Unsur Asia Pasific Colorectal Screening (APCS). Jurnal Penyakit Dalam Indonesia 2(2): 90-95.

Pais R, Horatiu S, Alina C.S dkk. 2012. Metabolic Syndrome and Risk of Subsequent Colorectal Cancer. World Journal of Gastroenterology 15(41): 5141-5148. Available from: https://www.ncbi.nlm.nih.gov/pm c/articles/PMC2773892/pdf/WJG15-5141.pdf

Rahdi D.R, Agung A.W, Lena.R . 2015. Gambaran Faktor Risiko Pasien Kanker Kolorektal Di RSUD Ulin Banjarmasin Periode AprilSeptember 2014. Jurnal Berkala Kedokteran 11(2): 221-232.

Sudoyo AW, Bambang.S, Idrus A, dkk, editor . 2016. Buku Ajar IImu Penyakit Dalam. Jakarta: Pusat Penerbitan Departemen IImu Penyakit Dalam Fakultas Kedokteran Universitas Indonesia

Tabuchi M, Kitayama J, Nagawa H. 2012. Hyperglycemia and Hypertriglyceridemia may Associate with The AdenomaCarcinoma Transition in Colorectal Epithelial Cells, J Gastroenterol Hepatol 12(8):1261-1264. Available from https://www.ncbi.nlm.nih.gov/pm c/articles/PMC4124439/pdf/wjg12-1261.pdf

WHO. 2014. Cancer. International Agency Of Research on cancer', World Health Organization. Available from https://doi.org/10.3945/an.116.0 12211 